\title{
Development pattern of an infralittoral bryozoan community in the western Mediterranean Sea*
}

\author{
Eva Pisano \& Massimo Boyer \\ Istituto di Anatomia Comparata dell' Universita', Via Balbi, 5 - Genova, Italy
}

\begin{abstract}
The developmental pattern on artificial substrates of a bryozoan community at 3 and $15 \mathrm{~m}$ water depth has been studied in the Ligurian Sea (Italy) for increasing periods of time ( 2 to 25 mo). A recruitment period - larval settlement and growth to saturation (increasing number of species and abundance) - is followed, after $12 \mathrm{mo}$, by a maturation period in which biotic interactions become predominant due to decreasing availability of primary substrate. During maturation, community structure changes considerably due to variation in quantitative relations among bryozoans; a definite replacement of species does not occur. Interactions between zoarial types can be traced back to several schemes resulting from combined reciprocal inhibition and enhancement actions. The community at $15 \mathrm{~m}$ depth does not show any difference in developmental pattern, but colonization is slower
\end{abstract}

\section{INTRODUCTION}

In the last few decades many studies of marine benthic communities have focused on the succession problem. Starting from objecting to the generalized deterministic classical model (Clements 1916, Margalef 1968, Odum 1969) a whole series of successional models has been proposed and described based upon specific research regarding marine communities (Sutherland 1974, 1978, Connell \& Slatyer 1977, Osman 1977, Sutherland \& Karlson 1977, Sousa 1979, 1980, Dean \& Hurd 1980, Chalmer 1982, Greene \& Schoener 1982). The definition and development of various models and the analysis of the mechanisms determining succession have gone hand in hand with an increasing knowledge of the structure and organization of marine benthic communities, especially behavioural strategies and interactions between species such as predation and competition (e.g. Dayton 1971, Stebbing 1973, Paine 1974, Connell 1975, Menge \& Sutherland 1976, Jackson 1977a, 1979a, Buss 1979, Karlson \& Jackson 1981, Rubin 1982).

The real meaning of the term 'succession' is being modified in the course of time to the extent that it now simply stands for the ensemble of progressive modifications observed in the community's composition

\footnotetext{
- Presented as unpublished poster at the 19th European
} Marine Biology Symposium, Plymouth, England, 1984 through time (Greene \& Schoener 1982), and it is becoming a synonym for community development.

The problem has also been approached by various authors in a more typically descriptive way. The evolution of benthic populations on natural and artificial substrates was divided up into well-defined stages by determining the main categories of environmental factors governing the development process while looking for signs that the final stage or climax has been reached (Simon Papyn 1965, Bellan Santini 1970, Huvé 1970, Castric Fey 1974, Castric 1977). The importance of some physical and biotic factors in controlling community development has been underlined by research in caves (Vacelet 1976, Harmelin 1980, 1983), a relatively simple environment due to the predominating influence of a comparatively small number of environmental factors and their stability.

In most of the research on this topic artificial substrates have been employed (e.g. W.H.O.I. 1952, Osman 1977, Sutherland \& Karlson 1977, Greene \& Schoener 1984). The size of the substrate (e.g. Jackson 1977b, Osman 1977), its positioning and spacing (e.g. Vandermeulen \& De Wreede 1982), the material used and the configuration of the substrate (e.g. Hart 1977 , Balduzzi \& Deandreis 1980, Riggio \& Di Pisa 1981), and their influence on colonization and community development have also been studied.

The data discussed in this paper were collected during an experimental investigation of the develop- 
ment of hard substrate benthic communities started in 1976 and still under way along a cliff of the Portofino Promontory (Sará 1979, Pisano et al. 1980, Relini et al. 1983). In particular we consider here bryozoans settled on artificial substrates submerged at 2 different depths for periods ranging between 2 and $25 \mathrm{mo}$ in order to attempt to establish the main colonization stages and to single out the possible variations with depth in community development.

Bryozoans play an important rôle in biological concretion processes (Harmelin 1980, Hong 1982), and they are one of the main components, both as to the number of species and to their abundance, of communities settling on artificial substrates in this biotope (Pisano 1979, Boyer 1984); for these reasons they strongly affect the structure of the whole community and probably reflect its main changes during developmental processes.

\section{STUDY AREA AND METHODS}

The field experiment was performed near the promontory of Portofino (Ligurian Sea: $44^{\circ} 18^{\prime} \mathrm{N}, 9^{\circ} 13^{\prime} \mathrm{E}$ ), along a submerged cliff, a vertical puddingstone wall that faces northeast and is relatively sheltered from direct light and wave action. Water movement and light decrease with depth, while sedimentation rate increases, becoming important from $10 \mathrm{~m}$ depth downwards. In the first $10 \mathrm{~m}$ the cliff community is characterized by brown algae, especially Dictyopteris membranacea; below this level, the amount of this large alga decreases, and the calcareous biological concretion, built up mainly by encrusting red algae, serpulids and bryozoans, is much thicker. Further environmental details can be found in Sará et. al. (1978) and Pisano \& Balduzzi (in press).

The bryozoan community on panels at Portofino has been previously studied and described in detail (Boyer 1984, Pisano \& Balduzzi in press) to investigate both the structural variations along the cliff and the general colonization trend at the different depths. Here we focused on the developmental patterns at 3 and $15 \mathrm{~m}$, that is in 2 quite differentiated ecological situations (Pisano \& Balduzzi in press). We have attempted to describe the subsequent steps of colonization and community evolution, chiefly looking at the variations in quantitative relations between the mean bryozoan zoarial groups.

We studied 2 series of experimental plates $(300 \times$ $200 \times 3 \mathrm{~mm}$ asbestos-cement panels) submerged at each depth for periods of $2,3,4,6,12$ and 25 mo. For immersion periods shorter than 12 mo the panels were submerged in opposite seasons (summer and winter) in order to take into account seasonal effects on species recruitment. The panels were placed on metal frames and set vertically at a distance of about $10 \mathrm{~cm}$ from the rocky surface with 1 side directly exposed to light and water movement and the other side shaded and sheltered. The 2 sides were analysed separately. The whole surface of each panel was examined under a dissecting microscope and every species was censused. Quantitative data were expressed in terms of species frequency: each panel side was divided into a grid of 100 unit surfaces, the frequency of each species representing the number of unit surfaces where that species was present.

We considered the following descriptive parameters of the community structure:

$\mathrm{S}=$ number of species;

$\mathrm{N}=$ abundance;

$\mathrm{H}=$ diversity index (Shannon-Weaver 1949);

$\mathrm{E}=$ evenness index (Daget 1976).

Cluster analysis (mean single bond method) was made on the similarity index value of Sorensen (1948) and Kulczynski (1927).

\section{RESULTS}

The bryozoan community of Portofino panels was found to be very rich in species, including 74 gymnolaemates, 70 of which were cheilostomates and 4 ctenostomates (Boyer 1984, Pisano \& Balduzzi in press).

The cluster analysis (Fig. $1 \mathrm{~A}, \mathrm{~B}$ ) shows a generally low affinity between substrate communities as immersion time increases and little compact grouping. A fair affinity is found at $3 \mathrm{~m}$ depth between communities of between 4 and 12 mo (with some differentiation between the exposed and the shaded side), leading to the identification of a fairly homogeneous group from which the 25 mo community stands out, especially from the quantitative viewpoint. This does not, however, apply at the greater depth where the analysis bring to light no large structural variation in the 12 to 25 mo period.

The trends of the community structure's descriptive parameters (Fig. 2A, B) make it possible to identify some main development steps. At $3 \mathrm{~m}$ depth, the number of species (S) and abundance (N) tended to stabilize approximately at their maximum values after having varied greatly in the first 4 mo. The number of species reached its saturation level at $12 \mathrm{mo}$, while abundance continued to increase slightly. Diversity and evenness curves also start to stabilize from the 6 th month. At the greater depth all parameters considered varied substantially up to $12 \mathrm{mo}$; no tendency towards saturation was observed especially in the values of the shaded sides of the substrates. In particular, species 
Fig. 1. Similarity dendrograms for panels submerged for periods of 2 to 25 mo at $3 \mathrm{~m}$ depth (A) and $15 \mathrm{~m}$ depth (B). Affinity between panel communities is based on Sorensen's qualitative index (S) and Kulczynski's quantitative index (K). Numbers indicate submersion times in months. Open circles: exposed side of panels; filled circles: sheltered side

Fig. 2. Trend through time of species number $(\mathrm{S})$, abundance $(\mathrm{N})$, diversity $(\mathrm{H})$ and evenness (E), at $3 \mathrm{~m}$ depth (A) and $15 \mathrm{~m}$ depth (B). Open circles: exposed side of panels; filled circles: sheltered side

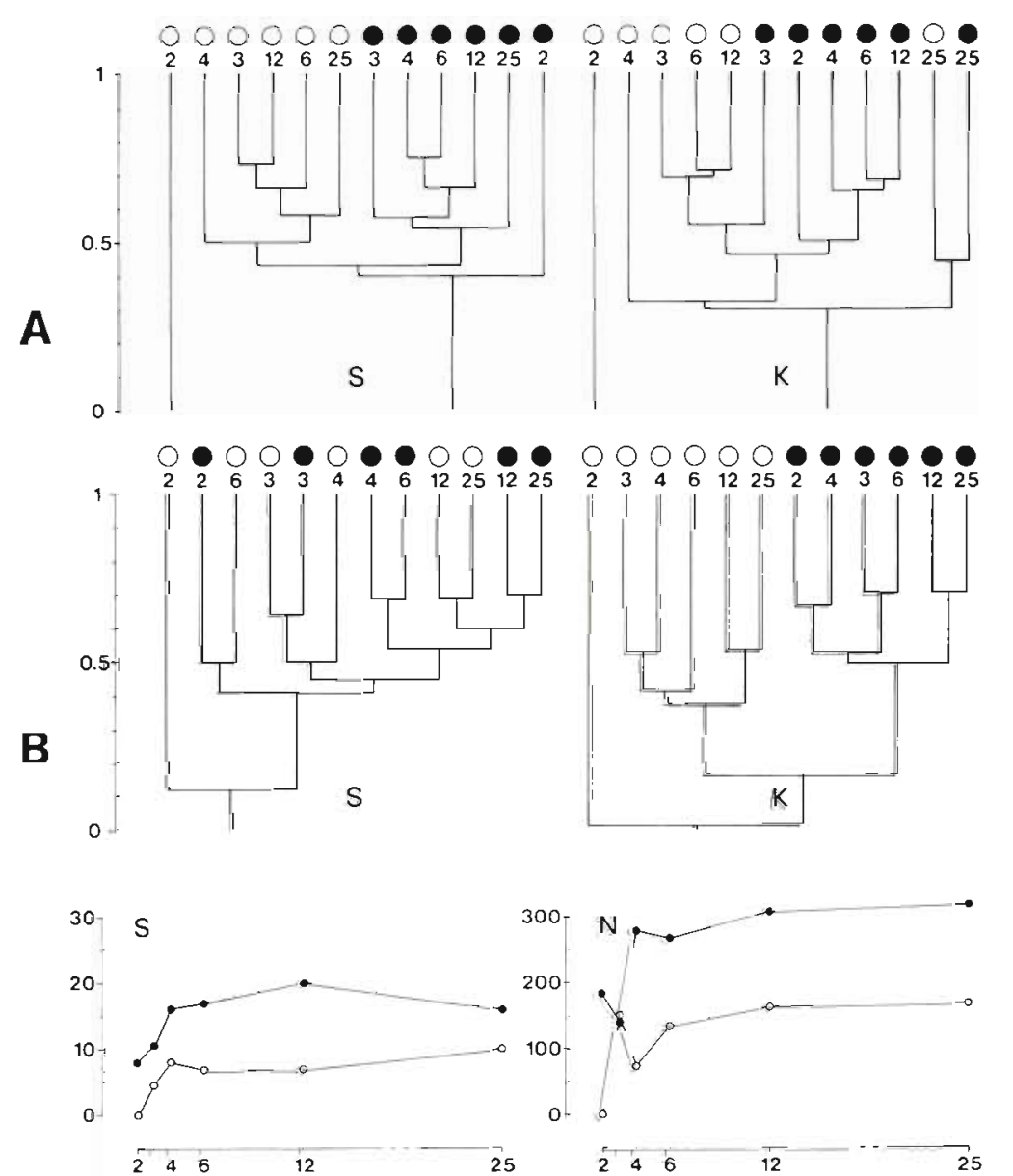

A
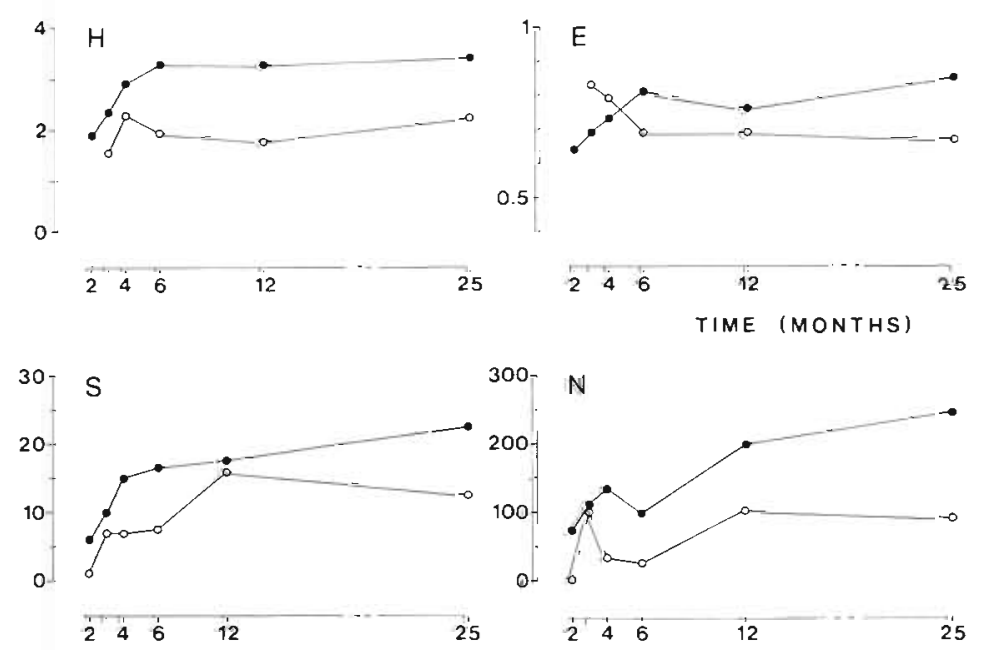

B

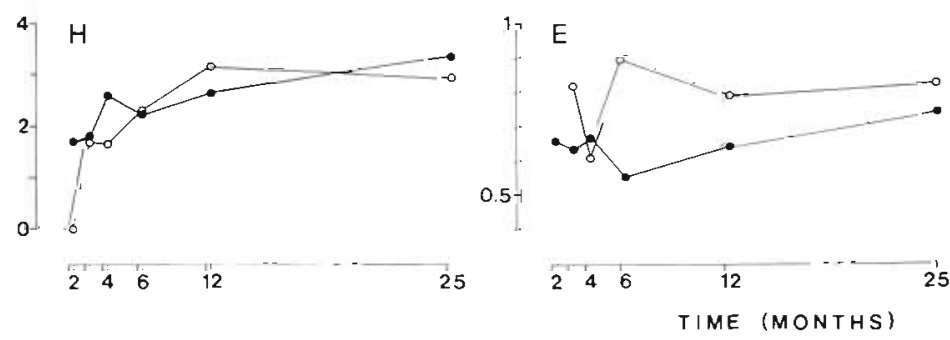


number and abundances clearly continued to increase between the 12th and 25th month.

The probability for each bryozoan species - as for other sessile organisms - of survival in a given environment is strongly conditioned by the general organization (shape, size, pattern of growth) of the colony (Stach 1936, Cheetham 1963, 1966, Lagaaij \& Gautier 1965, Harmelin 1976, Jackson 1979b). Thus we believe that variations in the relative abundances of zoarial types in a developing community can indicate modifications of the environment corresponding with different developmental stages.

We have taken into consideration the following zoarial types, including most of the species present at Portofino.

Thin membraniporiform type. This includes species with membraniporiform zoary (Stach 1936), unilaminate, thin, attached to the substrate, mainly settling on flat and smooth supports such as algal fronds. Species of this group found on our panels are listed in Table 1.

Table 1. Bryozoan species of thin membraniporiform type found on panels

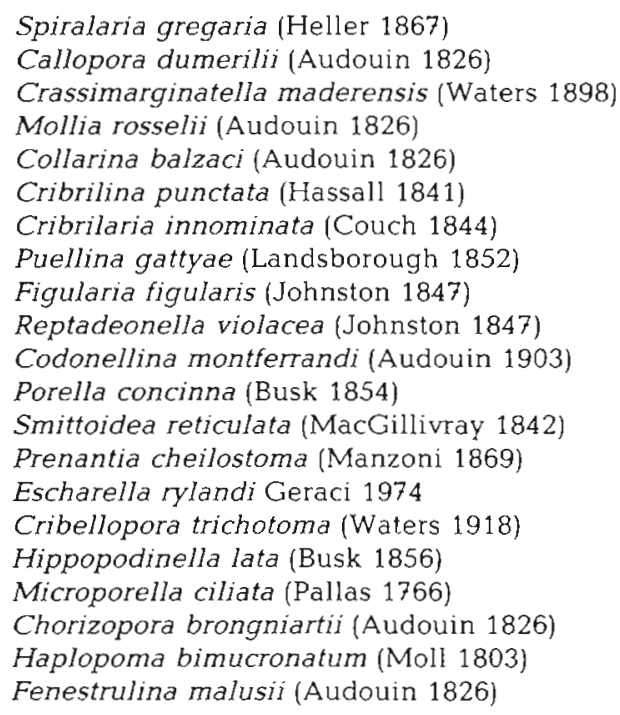

Thick membraniporiform type. This includes species with membraniporiform zoary of greater thickness than the foregoing and having a greater morphological plasticity with the possibility of forming several superimposed layers or of lifting the colony edges above the substrate, so as to adapt themselves to irregular surfaces (Table 2).

Creeping type. This includes species whose colonies form ramified uniseriate chains with the capacity to settle and grow on many kinds of support (Table 3 ).

Tuft-Iike type. Includes erect, ramified and flexible
Table 2. Bryozoan species of thick membraniporiform type found on panels

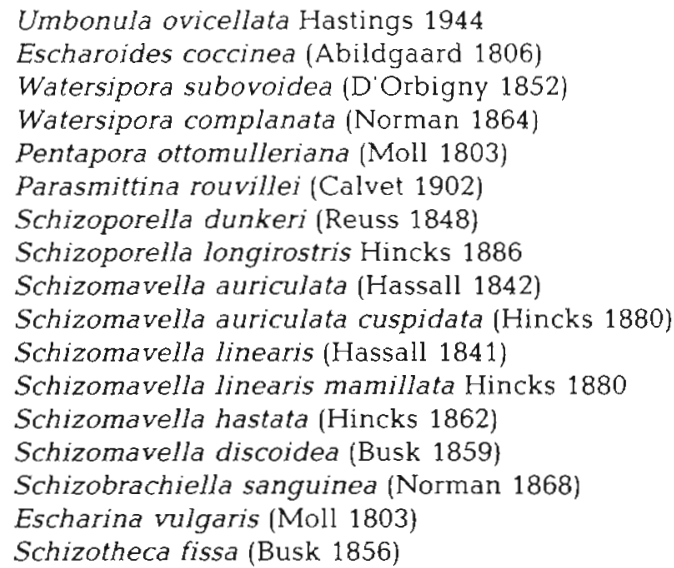

Table 3. Bryozoan species of creeping type found on panels

Aetea anguina (Linnaeus 1758)

Aetea sica (Couch 1844)

Aetea truncata (Landsborough 1852)

Beania mirabilis (Johnston 1839)

Table 4. Bryozoan species of tuft-like type found on panels

Caberea boryi (Audouin 1826)

Scrupocellaria delilii (Audouin 1826)

Scrupocellaria reptans (Linnaeus 1758)

Scrupocellaria scrupea Busk 1851

Scrupocellaria scruposa (Linnaeus 1758)

Bicellariella ciliata (Linnaeus 1758)

Bugula aquilirostris Ryland 1960

Bugula gautieri Ryland 1961

Bugula calathus calathus (Ryland 1968)

Bugula flabellata (Thompson in Gray 1847)

Bugula cfr. simplex Hincks 1886

Bugula spicata Hincks 1886

zoaries needing no large surfaces on which to settle and grow (Table 4).

At $3 \mathrm{~m}$ depth (Fig. 3A) during the initial colonization stage ( 2 and $3 \mathrm{mo}$ ) membraniporiform types are predominant, whereas creeping and tuft-like types are present chiefly from the 4 th month. A drastic change in the zoarial spectrum occurs between the 12 th and 25 th month due to the dramatic decrease of membraniproriform types, especially thin membraniporiform bryozoans, and the considerably increased number of tuft-like type.

At $15 \mathrm{~m}$ depth (Fig. 3B) the situation is quite different, especially on long-term immersed substrates; the most striking fact is the small incidence of tuft-like 


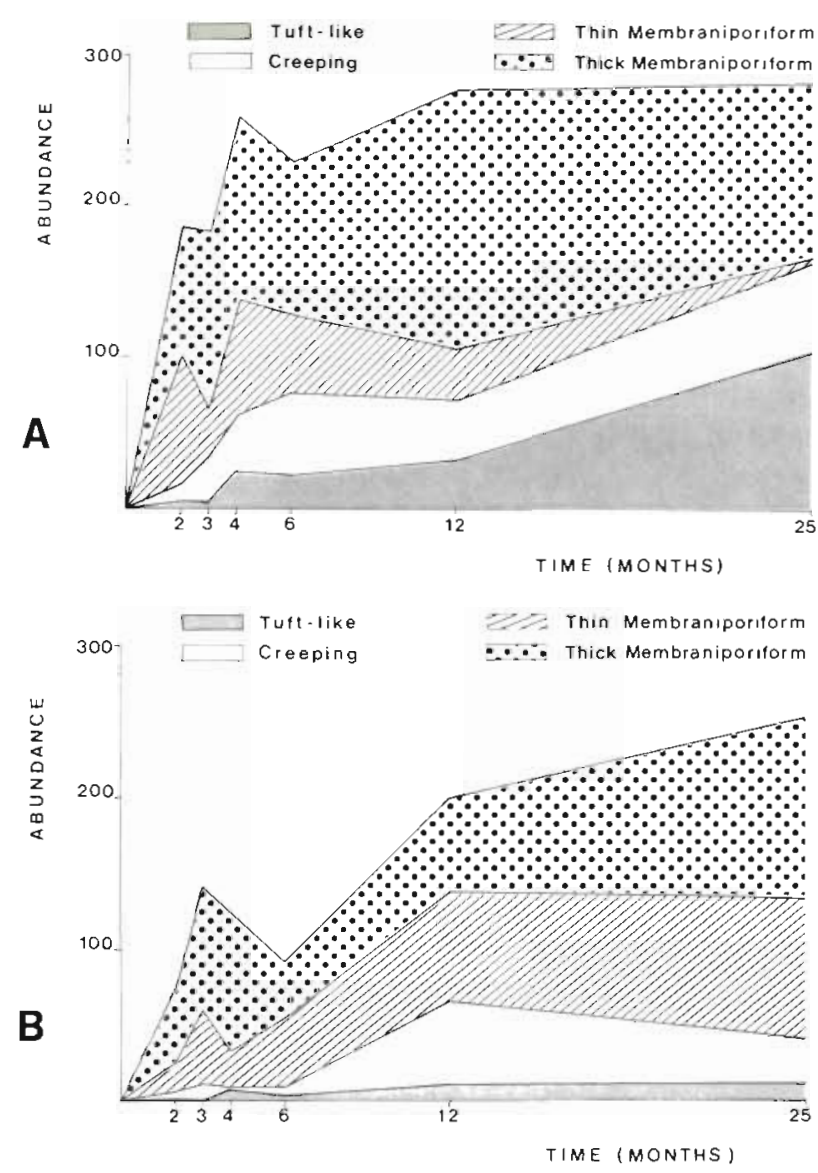

Fig. 3. Variation in time in main zoarial types abundance (on sheltered side of panels) at $3 \mathrm{~m}$ depth (A) and $15 \mathrm{~m}$ depth (B)

zoaries during all $25 \mathrm{mo}$, and the progressively growing numbers of the 2 membraniporiform types.

\section{DISCUSSION}

The bryozoan community development pattern derived from our experiment includes the following 2 main steps.

Recruitment period. This is characterized by larval settlement and growth of species able to fix onto the panel surface, up to saturation of species number ( $S$ ) and abundance $(\mathrm{N})$, coinciding with almost complete occupation of the primary space.

During an initial recruitment stage (first $4 \mathrm{mo}$ ) the species settle and grow at a fairly high rate causing strong variations in the community structure, as can be observed from the trend of the curves $\mathrm{S}, \mathrm{N}, \mathrm{H}$ and $\mathrm{E}$ (Fig. 2A) as well as from the cluster analysis (Fig. 1A). Membraniporiform zoarial types prevail during this initial stage (Fig. 3A), favoured by the availability of extensive free and smooth surfaces on which they are fast-growing.
The more advanced stage of the recruitment period is characterized by a more modest variation in the community structure, up to the saturation of the number of species and abundance and to the stabilization of diversity and evenness. Most of the available area will be occupied by thick membraniporiform species now starting to predominate over thin membraniporiform types; creeping species are more abundant.

While at $3 \mathrm{~m}$ depth the recruitment period can be deemed completed after $12 \mathrm{mo}$, at $15 \mathrm{~m}$ it was not completed even at the end of our experiment.

With reference to other colonization experiments carried out in the Western Mediterranean Sea for similar periods, our recruitment period may correspond to what Huve (1970) calls the 'étape de colonization' in the re-establishment of an infralittoral algal community in the gulf of Marseilles. A certain likeness is also found with the 'phases de recrutement' and ' $d$ ' installation' described by Castric Fey (1974) and Castric (1977) for a community in the English Channel, where in 11 mo about $75 \%$ of the species growing on the surrounding rocks settled on the artificial substrates.

During this whole period, community development is mainly controlled by physical factors (Castric 1977) and is not only affected by seasonal phenomena but is also strongly conditioned by the presence of a newly available settling space (Pisano \& Balduzzi, in press).

Maturation period. This is only observed at the shallower depth $(3 \mathrm{~m})$. It starts after about $12 \mathrm{mo}$, when substrate cover reaches values of about $100 \%$ (Pisano et al. 1980) and is characterized by the increasing predominance of biotic interactions due to the decreasing availability of primary substrate. Replacements of species are seldom observed (Boyer 1984, Pisano \& Balduzzi in press) and no pioneer species, as defined by Castric (1977), are known, while the community structure changes considerably with variations in quantitative relations between bryozoans. Substantial quantitative reductions affect the thick and, especially, the thin membraniporiform zoarial types (Fig. 3A), which are more fiercely involved in the competition for space. Furthermore, increase of tuft-like colonies indicates modifications occurring on panel surfaces and within the community which is now in a more advanced developmental stage.

The interactions between the various zoarial types, inferred from related quantitative variations and from observations of the behaviour of the various species, especially regarding overgrowth (Boyer 1984), are schematically outlined in Fig. 4. These are essentially the inhibition of thin membraniporiform zoarial type (slowing down of the settlement rate due to modifications at substrate level and suppression of already settled colonies due to overgrowth, especially by thick 


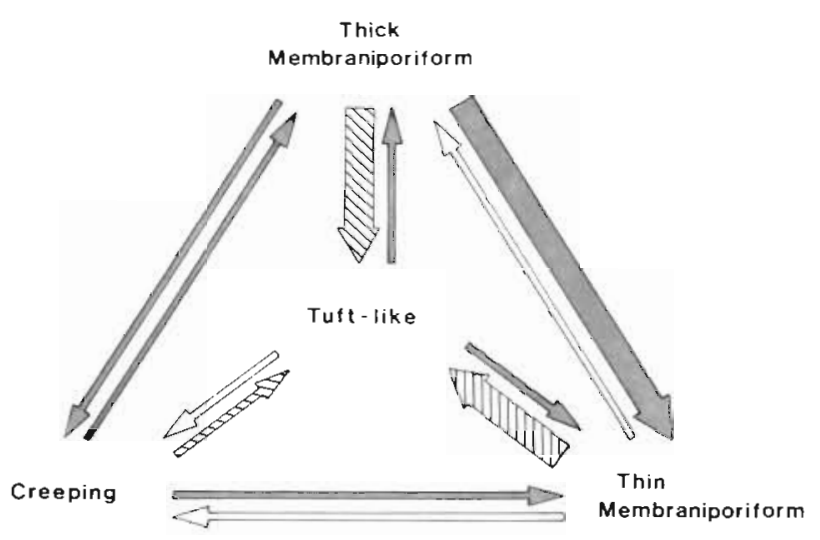

Fig. 4. Interactions between the main zoarial types. Stippled arrow = inhibiting action; striped arrow = enhancing action; white arrow $=$ very slight or indifferent action. Arrow thickness indicates interaction intensity

membraniporiform species) and the enhancement of tuft-like type by all other zoarial types.

This maturation period, which probably exceeds the 25 mo, has no equivalent at the greater depth. It is comparable with the 'étape de selection' mentioned by Huvé (1970).

Although more complete conclusions will be feasible only at the end of the research, after having examined longer-immersion panels and further replicates, the development pattern of Portofino's bryozoan community can allow the following remarks.

In the first place this pattern, making no particular provision for any pioneer or late species replacing the earlier ones, seems not in agreement with the classical succession theory according to which early colonists make modifications in the environment that are necessary for the establishment of later colonists and once the later arrivals become established, they render the conditions unsuitable for pioneer species. Even when considering more recent succession concepts, development in our bryozoan community does not conform exactly to any single successional model. However variations in the relative quantities of the zoarial groups during the maturation period are determined by a combination of different interactions described in various models (Connell \& Slatyer 1977, Osman 1977. Dean \& Hurd 1980, Greene \& Schoener 1982). The interactions observed by us can be led back to several schemes $(\mathrm{A} \underset{-}{\stackrel{+}{\rightleftarrows}} \mathrm{B} ; \mathrm{A} \underset{-}{\stackrel{\circ}{\rightleftarrows}} \mathrm{B} ; \mathrm{A} \underset{-}{\stackrel{-}{\rightleftarrows}} \mathrm{B} ; \mathrm{A} \underset{0}{\stackrel{*}{\rightleftarrows}} \mathrm{B})^{*}$ resulting from combined reciprocal inhibition and enhancement actions of variable intensity and partly corresponding to facilitation, tolerance and inhibition models (Connell \& Slatyer 1977).

\footnotetext{
- Where $\mathrm{A}$ and $\mathrm{B}=2$ different zoarial types; arrows indicate direction of actions;,,+- o indicate enhancing, inhibiting and indifferent actions, respectively
}

The absence of a significant replacement of species in the described developmental pattern might be due to the selectivity of the environment, which would allow only well-adapted and characteristic species to settle from the very first colonization; but more likely it results from a general slowness of the developmental processes of this community which would be, after 25 mo, still in a rather early developmental stage.

The latter hypothesis is in agreement with the available literature data regarding community development in non-polluted European sea-water (Simon Papyn 1965, Huvé 1970, Castric Fey 1974, Castric 1977. Harmelin 1983). On the other hand, in environments like harbours, lagoons and estuaries, with simplified resident communities (low species-number, low diversity), developmental processes appear to be faster (for the Mediterranean see literature cited in Relini 1980).

The differences between the 2 depths studied seem moreover to point to a general slow-down in community development at the greater depth rather than to a substantial differentiation in the developmental pattern. In fact the gradient of physical factors and the consequent gradual structural modifications of the community along the rocky wall affect the settlement and growth rate of most species (Boyer 1984), bringing about a more delayed colonization of the primary space at $15 \mathrm{~m}$ depth. Here free substrate remains available longer, with a consequent delay in the start of biotic interactions among bryozoans and in community maturation.

Acknowledgements. We are grateful to all colleagues for their assistance in the diving work and for their constructive comments on the manuscript. Research support was provided by CNR (Finalized Project 'Oceanografia e Fondi Marini') and by Italian Ministry of Education.

\section{LITERATURE CITED}

Balduzzi, A., Deandreis, G. (1980). Osservazioni sull' insediamento di Briozoi ed Entoprocti su superfici sperimentali di diversa natura immerse per quattro anni nel golfo del Tigullio (Riviera Ligure di Levante). Memorie Biol. mar Oceanogr 10 suppl.: 129-135

Bellan Santini, D. (1970). Salissures biologiques de substrats vierges artificiels immergés en eau pure, durant 26 mois, dans la région de Marseille (Méditerranée nord-occidentale). I. Etude qualitative. Téthys 2 (2): 335-356

Boyer, M. (1984). Ecologia dei Briozoi insediati su substrati artificiali nel piano infralitorale del promonotorio di Portofino (Mar Ligure). Tesi di laurea in Scienze Biologiche, Univ. Genova, p. 1-175

Buss, L. W (1979). Bryozoan overgrowth interactions. The interdependence of competition for space and food. Nature, Lond. 281: 475-477

Castric, A. (1977). Recruitement et succession du benthos rocheux sublittoral. In: Keegan, B. F., Ceidigh, P. O., Boaden, J. S. (ed.) Biology of benthic organisms. Pergamon Press, Oxford, p. 147-154 
Castric Fey, A. (1974). Les peuplements sessiles du benthos rocheux de l'archipel de Glénan (sud Bretagne). Ecologie descriptive. Thèse Fac. Sci. Univ. Paris, p. 1-133

Chalmer, P. N. (1982). Settlement pattern of species in a marine fouling community and some mechanisms of succession. J. exp. mar Biol. Ecol. 58 (1): 73-86

Cheetham, A. H. (1963). Late Eocene zoogeography of the eastern Gulf Coast region. Mem. geol. Soc. Am. 91 1-113

Cheetham, A. H. (1966). Cheilostomatous Polyzoa from the Upper Bracklesham Beds (Eocene) of Sussex. Bull. Br. Mus. nat. Hist. (Geol.) 13 (1): 1-115

Clements, F. E. (1916). Plant succession. Carnegie Inst. Washington Pub. 242: 1-512

Connell, J. H. (1975). Some mechanisms producing structure in natural communities: a model and evidence from field experiments. In: Cody, M., Diamond, J. (ed.) Ecology and evolution of communities. Harvard Univ. Press, Cambridge, Massachusetts, p. $460-490$

Connell, J. H., Slatyer, R. O. (1977). Mechanisms of succession in natural communities and their rôle in community stability and organization. Am. Nat. 111: 1119-1144

Daget, J. (1976). Les modèles mathérnatiques en écologie. Collection d'écologie, No. 8, Masson, Paris, p. 1-172

Dayton, P. K. (1971). Competition, disturbance, and community organization: the provision and subsequent utilization of space in a rocky intertidal community. Ecol. Monogr 41: 351-389

Dean, T. A., Hurd, L. E. (1980). Development in an estuarine fouling community: the influence of early colonists on later arrivals. Oecologia (Berl.) 46: 295-301

Greene, C. H., Schoener, A. (1982). Succession on marine hard substrata: a fixed lottery. Oecologia (Berl.) 55: 289-297

Greene, C. H., Schoener, A. (1984). Multivariate analysis of three-dimensional data in the study of succession in marine fouling communities. In: 6th International Congress on Marine Corrosion and Fouling. Marine Biology, Athens, Greece, Sept. 1984, p. 221-235

Harmelin, J. G. (1976). Le sous-ordre des Tubuliporina (Bryozoaires Cyclostomesi en Méditerranée. Ecologie et systématique. Mem. Inst. oceanogr. Monaco 10: 1-326

Harmelin, J. G. (1980). Etablissement des communautes de substrats durs en milieu obscur. Résultats préliminaires d'une expérience à long terme en Méditerranée. Memorie Biol mar. Oceanogr. 10 suppl.: 29-52

Harmelin, J. G. (1983). Etablissement des facies à Bryozoaires dans les milieux cryptiques méditerranéens. Rapp. Commn. int. Mer Médit. 28 (3): 259-261

Hart, D. D. (1977). The response of stream benthic invertebrate communities to microspatial substrate complexity Bull. ecol. Soc. Am. 58: 37

Hong, J. S. (1982). Contribution a l'étude des peuplements d'un fond de concretionnement coralligène dans la région Marseillaise en Méditerranée nord-occidentale. Bull. KORDI (Korla Ocean Research \& Development Institute) $4: 27-51$

Huvé, M. P. (1970). Recherches sur la génèse de quelques peuplements algaux marins de la roche littorale dans la région de Marseille. Thèse Fac. Sci. Univ. Paris, p. 1-479

Jackson, J. B. C. (1977a). Competition on marine hard substrata: the adaptative significance of solitary and colonial strategies. Am. Nat. 111: 743-767

Jackson, J. B. C. (1977b). Habitat area, colonization, and development of epibenthic community structure. In: Keegan, B. F., Ceidigh, P. O., Boaden, P. J. S. (ed.) Biology of benthic organisms. Pergamon Press, London, p. 349-358

Jackson, J. B. C. (1979a). Overgrowth competition between encrusting Cheilostome Ectoprocts in a Jamaican cryptic reef environment. J. Anim. Ecol. 48: 805-823

Jackson, J. B. C. (1979b). Morphological strategies of sessile animals. In: Larwood, G., Rosen, B. R. (ed.) Biology and systematics of colonial organisms. Academic Press, London, p. 499-555

Karlson, R. H., Jackson, J. B. C. (1981). Competitive networks and community structure: a simulation study. Ecology 62 (3): $670-678$

Kulczynski, S. (1927). Die Pflanzenassoziationen der Pieninen. Bull. Intern. Acad. Polan. Sci. Lett, classe Sci. Math. Nat., sez. B. Sci. Nat. suppl. 2: 57-203

Lagaaij, R., Gautier, Y. V. (1965). Bryozoan assemblages from marine sediments of the Rhone delta, France. Micropaleontology 11 (1): 39-58

Margalef, R. (1968). Perspectives in ecological theory. Univ. Chicago Press, Chicago

Menge, B. A., Sutherland, J. B. (1976). Species diversity gradients: synthesis of the rôles of predation, competition, and temporal heterogeneity. A.m. Nat. 110 (973): 351-369

Odum, E. P. (1969). The strategy of ecosystem development. Science 164: 262-270

Osman, R. W. (1977). The establishment and development of a marine epifaunal community. Ecol. Monogr. 47: 37-63

Paine, R. T. (1974). Intertidal community structure. Experimental studies on the relationship between a dominant competitor and its principal predator. Oecologia (Berl.) 15: 93-120

Pisano, E. (1979). Osservazioni preliminari sui Briozoi di substrati artificiali immersi nel piano infralitorale del promontorio di Portofino (Mar Ligure). Atti Soc. Tosc. Sci. Nat., Mem., ser B, suppl.: 320-322

Pisano, E., Balduzzi, A. (in press). Bryozoan colonization along an infralittoral cliff in the Ligurian Sea (NorthWestern Mediterrannean). In: Nielsen, C., Larwood, G. P. (ed.) Bryozoa: Ordovician to recent. Olsen \& Olsen, Fredensborg

Pisano, E., Bianchi, C. N., Relini, G. (1980). Insediamento su substrati artificiali lungo la falesia di Portofino (Mar Ligure): metodologie e dati preliminari. Memorie Biol. mar Oceanogr. suppl. 10: 269-274

Relini, G. (1980). Insediamento di organismi marini di substrato duro in ambienti portudi mediterranei. Memorie Biol. mar. Oceanogr., Suppl. X: 61-70

Relini, G., Bianchi, C. N., Matricardi, G., Pisano, E. (1983). Research in progress on colonization of hard substrata in the Liguria Sea. In: C.I.E.S.M. (ed.) Journée d'etudes sur les aspects scientifiques concernant les récifs artificiels et le mariculture suspendre. G. Comman, Monaco, p. 77-78

Riggio, S., Di. Pisa, G. (1981). The patterns of settlement of benthic Harbour Communities in relation to substratum geometry. Rapp. Comm. int. Mer Médit. 27 (2): 177-178

Rubin, J. A. (1982). The degree of intransitivity and its measurement in an assemblage of encrusting Cheilostome Bryozoa. J. exp. mar. Biol. Ecol. 60 (2): 119-128

Sará, M. (1979). Biocenosi bentoniche di substrato duro studio dei popolamenti e possibilitá di intervento per $\gamma$ incremento e la gestione delle risorse biologiche. In: CNR (ed.) Atti Conv. Sci. Naz. P. F. Oceanografia e Fondi Marini, Vol. 1. Roma, p. 135-144

Sará, M., Balduzzi, A., Boero, F., Pansini, M., Pessani, D., Pronzato, R. (1978). Analisi di un popolamento bentonico di falesia del Promontorio di Portofino. Dati preliminari. Boll. Mus. Ist. Biol. Univ. Genova 46: 119-137

Shannon, C. E., Weaver, W. (1979). The mathematical theory of communication. Univ. of Illinois Press, Urbana, p. 1-117

Simon Papyn, L. (1965). Installation expérimentale du 
benthos sessile des petits substrats durs de l'étage circalittoral en Méditerranée. Recl. Trav. Stn. mar. Endoume 39 (55): 53-94

Sorensen, $T$ (1948). A method of establishing groups of equal amplitude in plant sociology based on similarity of species content. Biol. Skr. 5: 1-34

Sousa, W. P. (1979). Experimental investigations of disturbance and ecological succession in a rocky algal community. Ecol. Monogr. 49 (3): 227-254

Sousa, W. P. (1980). The responses of a community to disturbance: the importance of successional age and species life histories. Oecologia (Berl.) 45: 72-81

Stach, L. W. (1936). Correlation of zoarial form with habitat. J. Geol. 44: 60-65

Stebbing, A. R. D. (1973). Competition for space between the epiphytes of Fucus serratus L. J. mar. biol. Ass. U. K. 53: $247-261$

Sutherland, J. P. (1974). Multiple stable points in natural communities. Am. Nat. 108: 859-873
Sutherland, J. P. (1978). Functional rôles of Schizoporella and Styela in the fouling community at Beaufort. North Carolina. Ecology 59 (2): 257-264

Sutherland, J. P. (1981). The fouling community at Beaufort North Carolina, USA: a study in stability. Am. Nat. 118 (4): $499-519$

Sutherland, J. P., Karlson, R. H. (1977). Development and stability of the fouling community at Beaufort, North Carolina. Ecol. Monogr. 47: 425-446

Vacelet, J. (1976). Les Spongiaires des grottes sous-marines obscures de la Méditerranée et des régions tropicales. Pubbl. Staz. zool. Napoli 40: 506-515

Vandermeulen, H., De Wreede, R. E. (1982). The influence of orientation of an artificial substrate (transite) on settlement of marine organisms. Ophelia 21 (1): 41-48

W.H.O.I. (1952). Marine fouling and its prevention. U. S. Naval Inst. Annapolis, Maryland

This paper was submitted to the editor; it was accepted for printing on July 29, 1985 